\title{
Identifikasi karakteristik akuifer dan potensi air tanah dengan metode geolistrik konfigurasi Schlumberger di Desa Arjosari, Kecamatan Kalipare, Kabupaten Malang
}

(Identification of aquifer properties and groundwater potential in Arjosari Village, Kalipare District, Malang Regency using Schlumberger configuration)

\author{
Listyo Yudha Irawan*1, Dicky Arinta*, Damar Panoto*, Irfan Helmi Pradana*, Rizal \\ Sulaiman**, Estrayudha Nurrizqi***, Ravinesh Rohit Prasad ${ }^{* * * *}$ \\ * Universitas Negeri Malang \\ ** Universitas Gadjah Mada, Yogyakarta \\ *** USAID Adaptasi Perubahan Iklim dan Ketangguhan (APIK) \\ **** Fiji National University, Fiji \\ ${ }^{1}$ Corresponding author, Surel: listyo.fis@um.ac.id
}

Paper received: 01-11-2021; revised: 10-11-2022; accepted: 15-01-2022

\begin{abstract}
Identification of groundwater potential through the characteristics of the aquifer layer is an important study. This is useful for knowing the availability of shallow groundwater in an area. Arjosari Village, Kalipare District, Malang Regency is an area that often experiences shortages in meeting daily water needs, especially during the dry season. The availability of groundwater at the research site is influenced by the area's topographical conditions, which range from flat to very steep.This study aims to identify the location of the aquifer and groundwater potential in Arjosari Village. This study uses the Schlumberger configuration to identify aquifers and groundwater. This method adheres to the basic principle that each rock layer has a different resistivity value. In addition to rock material type factors, the level of saturation and chemical composition in water affects the value of resistivity. The results showed that the aquifer characteristics and groundwater potential were different for each lithological condition, slope, soil type, and land use. In the research location, shallow aquifers were found less than 20 meters while there were also deep aquifers located more than 25 meters below the ground surface. Shallow aquifers can be used as a water source by the community, especially to meet their daily water needs. The results of this study are used for Geography learning on hydrological material.
\end{abstract}

Keywords: aquifers; groundwater; geoelectrical

\begin{abstract}
Abstrak
Identifikasi potensi airtanah melalui karakteristik perlapisan akuifer merupakan suatu kajian yang penting. Hal ini bermanfaat untuk mengetahui ketersediaan air tanah dangkal di suatu wilayah. Desa Arjosari, Kecamatan Kalipare, Kabupaten Malang merupakan wilayah yang sering mengalami kekurangan air dalam pemenuhan kebutuhan sehari-hari khususnya saat musim kemarau. Kondisi topografi wilayah yang bervariasi dari datar hingga sangat curam merupakan faktor yang mempengaruhi keterdapatan airtanah di lokasi penelitian. Penelitian ini bertujuan mengidentifikasi lokasi keberadaan akuifer dan potensi airtanah di Desa Arjosari. Penelitian ini menggunakan konfigurasi Schlumberger untuk mengidentifikasi akuifer dan airtanah. Metode ini berdasarkan prinsip dasar bahwa masing-masing perlapisan batuan mempunyai nilai tahanan jenis yang berbedabeda. Selain faktor jenis material batuan, tingkat kejenuhan dan komposisi kimia dalam air mempengaruhi nilai tahanan jenis. Hasil penelitian menunjukkan bahwa karakteristik akuifer dan potensi airtanah berbeda pada setiap kondisi litologi, kemiringan lereng, jenis tanah, dan
\end{abstract}


Jurnal Pendidikan Geografi:

Kajian, Teori, dan Praktik dalam Bidang Pendidikan dan Ilmu Geografi

$27(1), 2022,102-116$

penggunaan lahan. Di lokasi penelitian ditemukan akuifer dangkal kurang dari 20 meter sementara terdapat pula akuifer dalam yang terletak lebih dari 25 meter di bawah permukaan tanah. Akuifer dangkal dapat dimanfaatkan sebagai sumber air oleh masyarakat khususnya untuk memenuhi kebutuhan air sehari-hari. Hasil penelitian ini dimanfaatkan untuk pembelajaran geografi pada materi hidrologi.

Kata kunci: akuifer; air tanah; geolistrik

\section{Pendahuluan}

Peningkatan kebutuhan air untuk berbagai kebutuhan senantiasa bertambah secara pesat dari waktu ke waktu (Astutik et al., 2016). Permasalahan yang dihadapi saat ini adalah meningkatnya jumlah penduduk yang berakibat pada meningkatnya kebutuhan air bersih di setiap tahunnya (Ismawan, 2016). Penyediaan air bersih bagi masyarakat dapat diperoleh dari penyerapan air tanah, khususnya air tanah dangkal. Pemenuhan kebutuhan air dapat memanfaatkan air yang terdapat di bawah permukaan bumi. Namun demikian, ketersediaan jumlah yang tidak mencukupi dari air tanah dangkal merupakan kendala tersendiri bila kebutuhan meningkat dalam jumlah yang besar (Mishra, Khare, Gupta, \& Shukla, 2014).

Salah satu wilayah yang memerlukan pemanfaatan air tanah sebagai alternatif pemenuhan kebutuhan air bersih adalah Desa Arjosari, Kecamatan Kalipare, Kabupaten Malang, Indonesia. Desa ini memiliki permasalahan pemenuhan kebutuhan air bersih karena kurangnya ketersediaan sumber air permukaan. Luas wilayah Desa Arjosari sekitar 1.239 Ha dengan penggunaan lahan berupa sawah sebesar 169 Ha dan lahan kering sebesar 1.070 Ha. Berdasarkan data Kecamatan Kalipare dalam Angka 2021, Desa Arjosari mempunyai jumlah penduduk sebesar 6.933 jiwa dengan laju pertumbuhan penduduk per tahun 0,74 (BPS Kabupaten Malang, 2021). Kebutuhan air yang meningkat ini dapat dipenuhi dengan cara mencari potensi air tanah yang baru. Bagian awal yang harus dilakukan sebagai upaya menemukan potensi air tanah yang baru adalah dengan melakukan identifikasi susunan perlapisan bumi. Informasi tentang lapisan pembawa air (akuifer), ketebalan, kedalaman, dan kualitas air merupakan hal penting untuk diketahui. Akuifer pada umumnya ditemukan di pori batuan sedimen, daerah lipatan, celah batuan yang bersifat keras, dan di dalam gua karst (Winarni, Darsono, \& Legowo, 2014).

Informasi tentang karakteristik perlapisan batuan ini dapat dimanfaatkan untuk menemukan air tanah, sehingga dapat digunakan untuk memenuhi kebutuhan air bersih (Finke et al., 2004; Shah, 2008; Shantharam \& Elangovan, 2018; Sharma, 2009). Karakteristik perlapisan batuan dapat diketahui dengan menggunakan pendekatan ilmu geofisika, yakni metode geolistrik (Fitrianto, Supriyadi, Taufiq, Mukromin, \& Wardana, 2018). Metode geolistrik sebagai alat eksplorasi air tanah dapat dipakai di berbagai kondisi geologi (Fajana, Sanuade, Olawunmi, \& Oyebamiji, 2019). Geolistrik dapat memberikan informasi karakteristik bawah permukaan bumi seperti struktur bawah permukaan bumi (patahan, lipatan, rekahan, batuan lapuk, zona geser, batuan dasar), litologi, perlapisan stratigrafi, dan karakteristik geohidrologi melalui nilai resistivitas yang diperoleh (Akintorinwa, 2012; Oladunjoye \& Jekayinfa, 2015). Nilai resistivitas dihasilkan dari proses injeksi aliran arus listrik dua elektroda arus yang kemudian dibaca kembali oleh dua elektroda potensial (Supriyadi, Khumaedi, \& Putro, 2017). Penelitian ini bertujuan untuk melakukan identifikasi keberadaan akuifer dan potensi air tanah di Desa Arjosari. Dengan adanya kajian tersebut, maka dapat diperoleh informasi tentang sebaran akuifer dan potensi air tanah yang mampu digunakan 


\section{Jurnal Pendidikan Geografi:}

\section{Kajian, Teori, dan Praktik dalam Bidang Pendidikan dan Ilmu Geografi}

$$
\text { 27(1), 2022, 102-116 }
$$

sebagai pemenuhan kebutuhan air oleh penduduk Desa Arjosari. Selain itu hasil kajian dapat dimanfaatkan dalam pembelajaran Geografi pada materi hidrologi.

\section{Metode}

Desain penelitian ini adalah survey lapangan dengan menggunakan metode geolistrik untuk mengukur dan mengumpulkan data. Metode geolistrik merupakan salah satu cara untuk mendapatkan informasi keberadaan potensi air tanah (Faris, Suaidi, Sutrisno, Hasan, \& Broto, 2019; Rubiantoro, 2016; Uligawati \& Fatimah, 2020; Winarni et al., 2014). Metode ini berdasarkan prinsip dasar bahwa setiap perlapisan batuan memiliki nilai tahanan jenis yang berbeda-beda. Nilai tahanan jenis dipengaruhi oleh faktor jenis material batuan, faktor tingkat kejenuhan, dan komposisi kimia air. Berdasarkan hal tersebut, maka pendugaan perlapisan akuifer dapat dilakukan berdasarkan metode geolistrik.

Tahapan penelitian terdiri dari: 1) pra lapangan, 2) lapangan, dan 3) pasca lapangan. Tahapan pra lapangan berisi kegiatan pengumpulan data dan peta pendukung, antara lain: 1) Geologi (Peta Geologi Lembar Blitar 1507-6 Skala 1:250.000), 2) Kemiringan Lereng (DEM Alos Palsar), 3) Jenis Tanah (Peta Tanah, Skala 1:250.000), dan 4) Penggunaan Lahan (Citra Google Earth perekaman Tahun 2020). Tahapan lapangan berisi aktivitas pengambilan data geolistrik dengan Konfigurasi Sclumberger. Tahapan terakhir adalah pasca lapangan yang meliputi: pengolahan dan interpretasi data. Pengolahan data dilakukan dengan menggunakan perangkat lunak Progress. Tahapan penelitian disajikan pada Gambar 1.

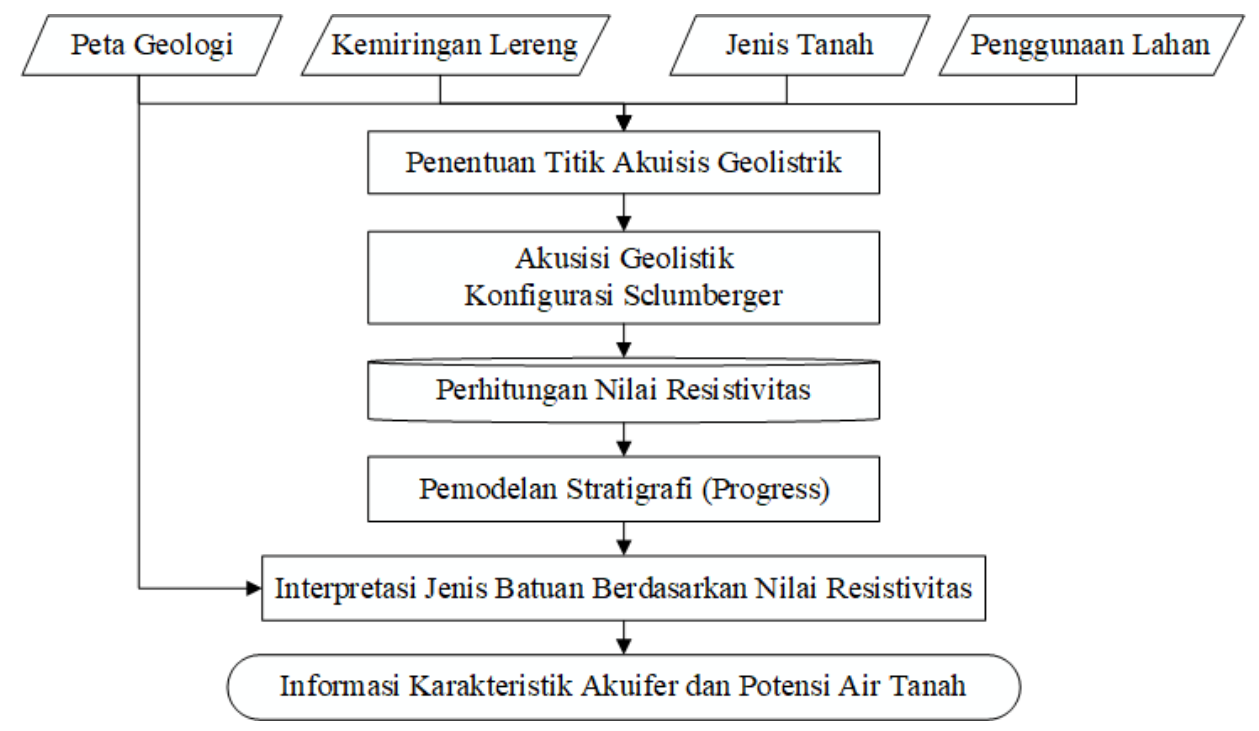

Gambar 1. Diagram Alir Penelitian

\subsection{Analisis Konfigurasi Schlumberger}

Penelitian ini menggunakan konfigurasi Schlumberger untuk mengidentifikasi akuifer dan air tanah. Selain Schlumberger, metode geolistrik memiliki banyak jenis konfigurasi dalam proses akuisisi data di lapangan, seperti Dipole-dipole, Wenner, Pole-pole, dan lain-lain (Akintorinwa, 2012). Metode Sclumberger telah menunjukan hasil yang baik dalam penelitianpenelitian sebelumnya karena dapat menjangkau kedalaman yang optimum, sehingga dapat menggambarkan karakteristik akuifer dengan tepat (Bharti et al., 2019). Identifikasi karakteristik akuifer dan potensi tanah dengan menggunakan metode geolistrik harus 


\section{Jurnal Pendidikan Geografi:}

\section{Kajian, Teori, dan Praktik dalam Bidang Pendidikan dan Ilmu Geografi}

$$
\text { 27(1), 2022, 102-116 }
$$

didukung dengan pengetahuan geologis yang baik. Hal ini disebabkan karena pengetahuan geologis berguna untuk memproses interpretasi jenis batuan didasarkan pada nilai resistivitas yang diperoleh.

Setiap jenis konfigurasi yang digunakan mempengaruhi nilai tahanan jenis semu yang dipole sewaktu akuisisi data di lapangan. Penyebabnya adalah karena setiap konfigurasi memiliki nilai faktor geometri $(\mathrm{K})$ yang berbeda-beda. Secara umum untuk memperoleh nilai resistivitas melalui Persamaan 1.

$\rho_{a}=K \frac{\Delta V}{I}$

Dimana:

$\begin{array}{ll}\rho_{a} & =\text { Nilai resistivitas } \\ \Delta V & =\text { Beda potensial } \\ K & =\text { Faktor geometri } \\ I & \end{array}$

Nilai faktor geometri (K) pada konfigurasi Sclumberger diperoleh dengan Persamaan 2.

$$
K=\pi\left(\frac{a^{2}-b^{2}}{2 b}\right)
$$

Dimana:

$$
\begin{array}{ll}
a & =\text { jarak antar elektroda arus A-B dalam meter } \\
b & =\text { jarak antar elektroda potensial M-N }
\end{array}
$$

(Fitrianto et al., 2018)

Konfigurasi Schlumberger memakai 4 elektroda (A, B, M, dan N) dan selama akuisisi spasi antar elektroda diperbesar secara berangsur-angsur. Susunan elektroda pada konfigurasi Schlumberger disajikan pada Gambar 2.

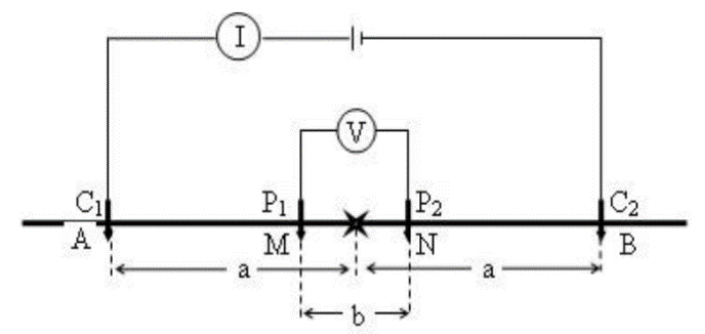

Gambar 2. Susunan Elektroda Konfigurasi Schlumberger

\section{Hasil dan Pembahasan}

Desa Arjosari terletak di wilayah Kecamatan Kalipare, Kabupaten Malang. Secara geografis, Desa Arjosari terletak pada $8^{\circ} 11^{\prime} 19.8^{\prime \prime}$ LS - 8 $8^{\circ} 14^{\prime} 16^{\prime \prime}$ LS dan $112^{\circ} 22^{\prime}$ 58.3" BT $112^{\circ} 25^{\prime} 30.5^{\prime \prime}$ BT. Berdasarkan data yang diperoleh dari pemerintah Desa Arjosari luas wilayahnya mencapai 1.239 Ha. Secara umum apabila dikelompokkan menurut jenis lahan, maka Desa Arjosari dapat dibagi menjadi dua, yaitu lahan sawah sebesar 169 Ha dan lahan kering sebesar 1.070 Ha. Wilayah desa ini terdiri dari enam dusun yaitu: Dusun Sidodadi, Mentaraman, Sumbertimo, Kedung Waru I, Kedung Waru II, dan Dusun Tumpakmiri. Gambar 3 adalah gambaran distribusi titik pengambilan sampel geolistrik di wilayah Desa Arjosari. 


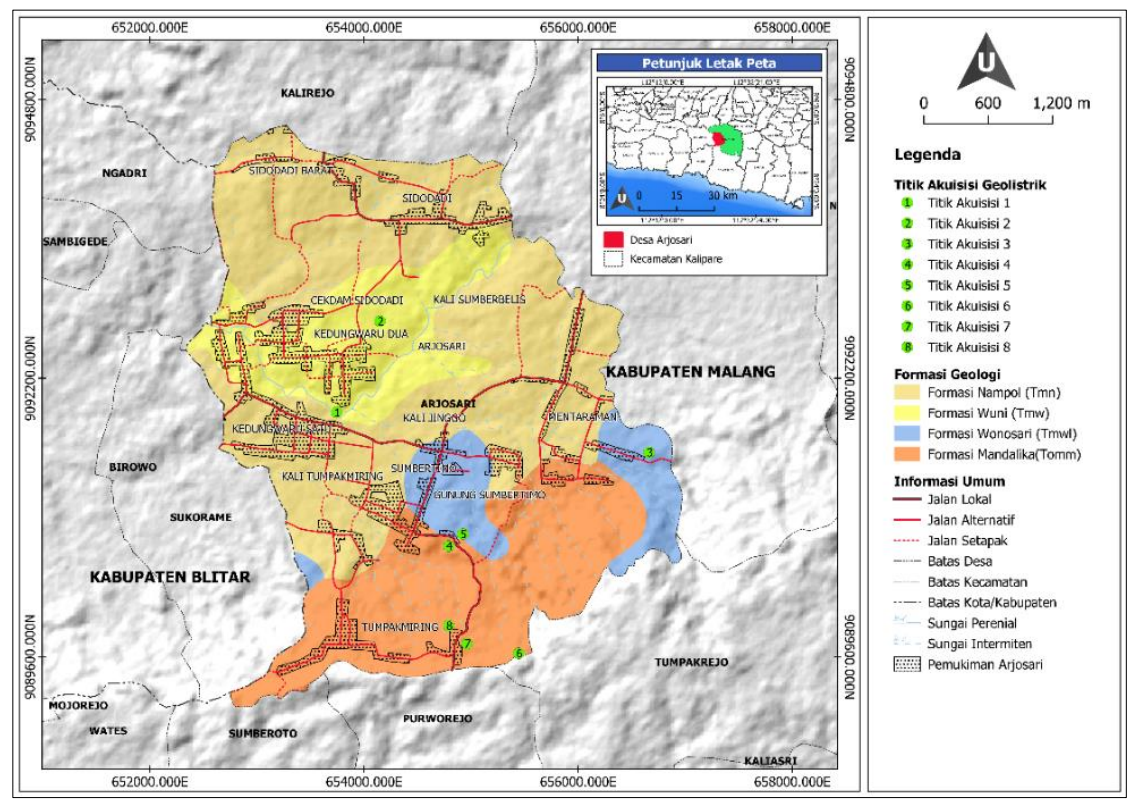

\section{Gambar 3. Peta Titik Akuisisi Geolistrik di Desa Arjosari}

Lokasi penelitian di Desa Arjosari ini merupakan salah satu daerah yang memiliki masalah berupa kesulitan air khususnya pada musim kemarau. Saat ini penduduk desa pada umumnya menggunakan air tanah dangkal dan air permukaan. Air permukaan didapatkan dengan cara membuat sumur gali dengan kedalaman berkisar antara 20 meter. Keringnya sumur gali dan berkurangnya volume air sungai pada saat musim kemarau mengakibatkan lahan pertanian yang berupa sawah dan ladang menjadi kurang produktif. Berdasarkan data kondisi hidrogeologi regional, wilayah Desa Arjosari termasuk dalam klasifikasi akuifer air tanah langka hingga daerah dengan akuifer produktif sedang-tinggi.

Berdasarkan temuan di lapangan diperoleh fakta bahwa lokasi penelitian sering mengalami kekeringan. Hal ini didukung pula dengan data kondisi hidrogeologi regional dimana sebagian besar berada pada akuifer produktif sedang. Berdasarkan kedua kondisi tersebut perlu penyelidikan lebih lanjut supaya diketahui penyebab kesulitan air di lokasi penelitian. Kondisi hidrogeologi regional biasanya lebih banyak didasarkan pada keterdapatan akuifer air tanah dalam sehingga di permukaan daerah ini dijumpai kering dan sulit air. Meskipun demikian apabila didasarkan pada data kondisi hidrogeologi regional, besar kemungkinan terdapat akuifer potensial air tanah dalam. Oleh sebab itu, perlu dilakukan pengenalan karakteristik akuifer bawah permukaan dengan metode geofisika konvensional (geolistrik tahanan jenis).

Penentuan sifat akuifer dapat didasarkan pada tiga parameter penting sebagai berikut: 1) tebal akuifer, 2) koefisien lolos atau permeabilitas, dan 3) hasil jenis. Tebal akuifer mulai diukur dari permukaan tanah (water table) sampai lapisan yang bersifat semi kedap air (impermeable) yang termasuk di dalamnya adalah akuiklud dan akuifug. Sedangkan nilai permeabilitas akuifer sangat ditentukan oleh tekstur dan struktur mineral atau partikel/butir penyusun suatu batuan. Apabila semakin kasar Apabila semakin kasar tekstur dengan struktur lepas suatu batuan, maka semakin tinggi batuan meloloskan air tanah. Sebaliknya apabila semakin halus tekstur dengan struktur semakin tidak teratur, maka semakin rendah kemampuan batuan untuk meloloskan sejumlah air tanah. Oleh karena itu setiap jenis batuan 


\section{Jurnal Pendidikan Geografi:}

\section{Kajian, Teori, dan Praktik dalam Bidang Pendidikan dan Ilmu Geografi}

$$
\text { 27(1), 2022, 102-116 }
$$

akan memiliki nilai permeabilitas yang berbeda dengan jenis batuan yang lainnya (Nurwidyanto, Yustiana, \& Widada, 2006). Sementara itu, Besarnya cadangan air tanah atau hasil jenis yang dapat tersimpan dalam akuifer sangat ditentukan oleh sifat fisik batuan penyusun akuifer (tekstur dan struktur butir-butir penyusunnya) (Darwis, 2018).

Pada penelitian ini interpretasi data geolistrik dilakukan untuk mengetahui nilai resistivitas setiap lapisan batuan, ketebalan lapisan, dan kedalaman lapisan batuan. Setelah memperoleh nilai tahanan jenis batuan, kemudian dikorelasikan dengan peta geologi daerah penelitian untuk mengetahui jenis litologi penyusun beserta tipe akuifer. Perhitungan nilai resistivitas menunjukkan potensi keterdapatan air tanah. Kondisi fisiografis Desa Arjosari ditampilkan pada Gambar 4, 5, dan 6.

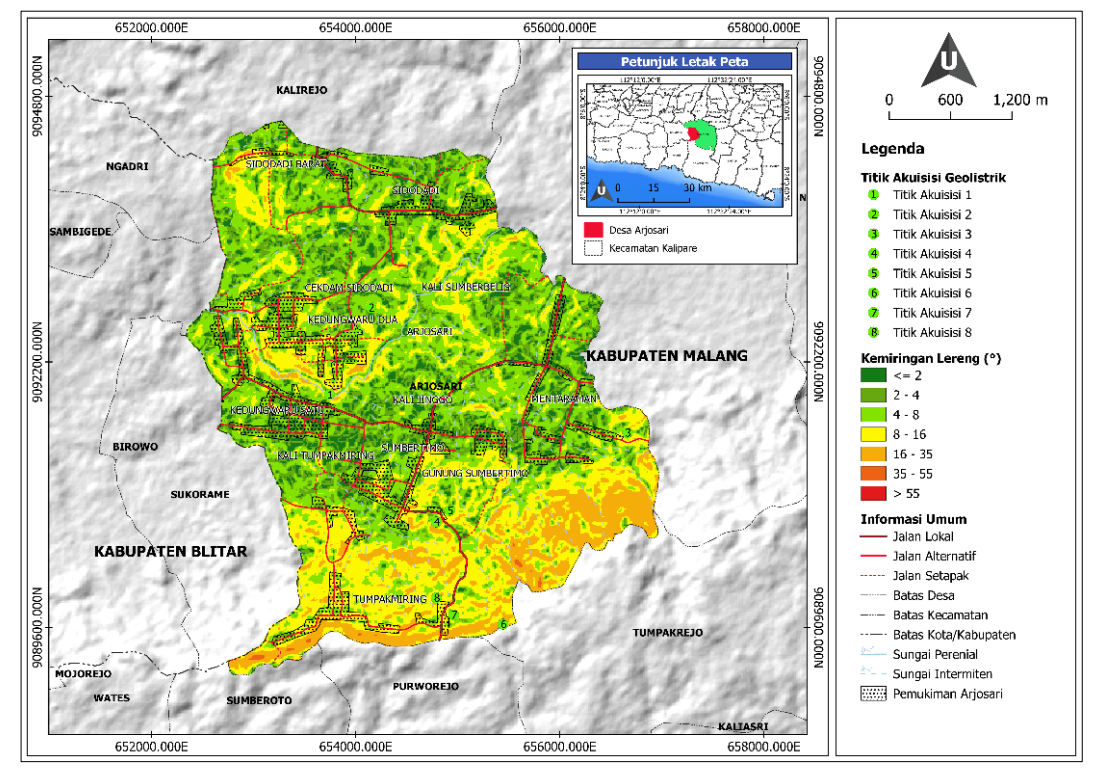

Gambar 4. Peta Kemiringan Lereng Desa Arjosari

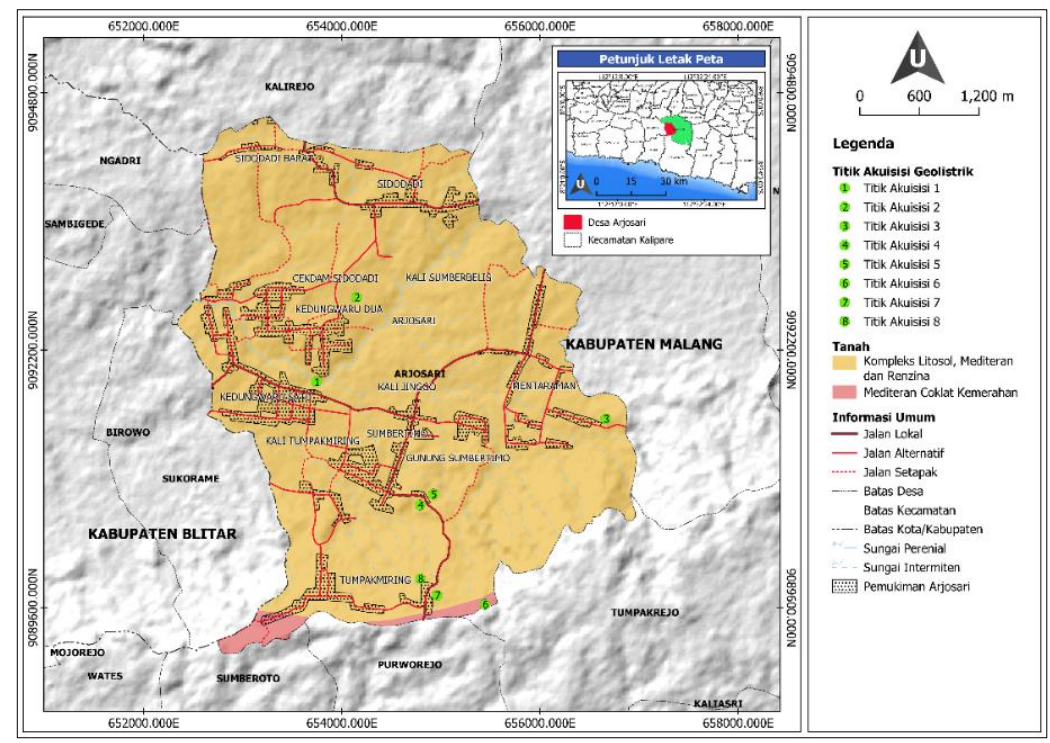

Gambar 5. Peta Jenis Tanah Desa Arjosari 


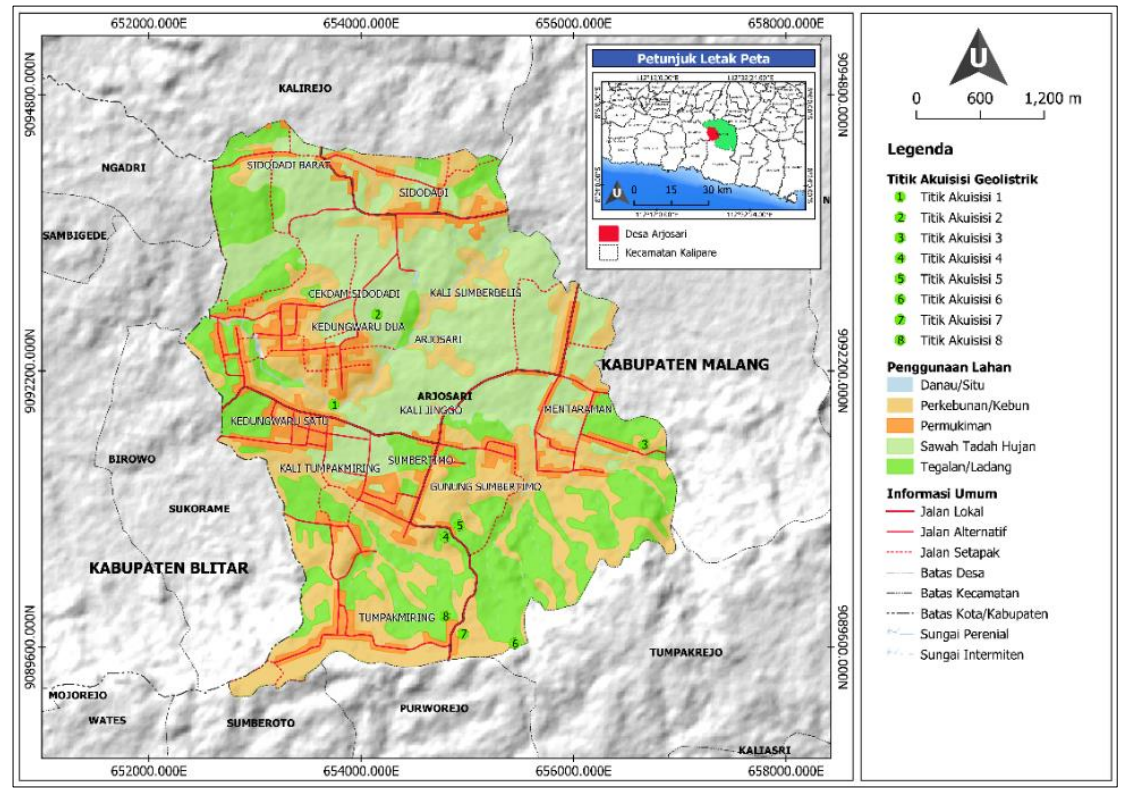

\section{Gambar 6. Peta Penggunaan Lahan Desa Arjosari}

Penentuan pengambilan sampel untuk titik akuisisi geolistrik didasarkan pada kondisi fisiografis wilayah meliputi geologi, kemiringan lereng, tanah, dan penggunaan lahan. Terdapat beberapa titik sebagai bahan pertimbangan lokasi pemilihan sampel beserta penjelasan ringkas terkait kondisi fisiografis wilayah pada tiap-tiap titik lokasi pengamatan. Penjelasan pada setiap titik pengambilan sampel disajikan pada Tabel 1.

\subsection{Lokasi Pengambilan Sampel 1: Dusun Kedungwaru Lintasan 1 (653618, 9091442 UTM 49S)}

Hasil pengumpulan data di lapangan dan analisis menunjukan bahwa pada titik akuisisi pertama berada di Dusun Kedungwaru. Titik ini memiliki potensi air tanah yang berada pada daerah cekungan. Kondisi ini berpotensi untuk dibangun sumur bor yang dapat dimanfaatkan untuk keperluan pemenuhan kebutuhan air bersih oleh penduduk. Selain itu, hasil survey lapangan juga menunjukan bahwa titik tersebut berada pada posisi yang ideal tidak begitu jauh dari permukiman penduduk.

Hasil pemodelan untuk perlapisan hidrostratigrafi dapat diklasifikasikan menjadi akuiklud, akuifer, dan akuifugada. Lokasi ini diperkirakan berada di kedalaman 5-25 m. Lapisan ini diinterpretasikan sebagai batu pasir yang berada pada kondisi jenuh air (akuifer). Kondisi titik akuisisi 1 dapat dilihat pada Gambar 7.

\subsection{Lokasi Pengambilan Sampel 2: Dusun Kedungwaru Lintasan $2(654142,9092664$ UTM 49S)}

Lokasi pengambilan sampel kedua masih berada di Dusun Kedungwaru. Karakteristik potensi air tanah di lokasi ini mirip dengan lokasi titik pertama yaitu memiliki potensi air tanah yang berada pada daerah cekungan serta dapat dimanfaatkan untuk sumur bor. Lokasi titik akuisisi kedua juga berdekatan dengan permukiman penduduk sehingga apabila dibangun sumur bor akan memudahkan penggunanya. 


\section{Jurnal Pendidikan Geografi:}

Kajian, Teori, dan Praktik dalam Bidang Pendidikan dan Ilmu Geografi

$$
27(1), 2022,102-116
$$

Berdasarkan hasil perhitungan nilai resistivitas, potensi adanya air tanah pada lokasi ini diperkirakan berada di kedalaman sekitar $20 \mathrm{~m}$. Lapisan ini diinterpretasikan sebagai batu pasir yang berada pada kondisi jenuh air (akuifer). Kenampakan kondisi litologi, sifat batuan, dan potensi air tanah dapat dilihat dalam Gambar 8.

Tabel 1. Keterkaitan Kondisi Fisiografis Wilayah untuk Identifikasi Awal Potensi Air Tanah

\begin{tabular}{|c|c|c|c|c|}
\hline Lokasi & Formasi Geologi & $\begin{array}{l}\text { Kemiringan } \\
\text { Lereng }\end{array}$ & Jenis Tanah & $\begin{array}{l}\text { Penggunaan } \\
\text { Lahan }\end{array}$ \\
\hline 1. & $\begin{array}{l}\text { Formasi Nampol (Tmn): } \\
\text { Batu pasir } \\
\text { gampingantuffan, batu } \\
\text { lempung, dan napal }\end{array}$ & Datar & $\begin{array}{l}\text { Kompleks Litosol } \\
\text { Mediteran dan } \\
\text { Renzina }\end{array}$ & Sawah \\
\hline 2. & $\begin{array}{l}\text { Formasi Wuni (Tmw): } \\
\text { Breksi andesit-basal, lahar } \\
\text { breksi, lava andesit dan } \\
\text { sisipan batu pasir tufan }\end{array}$ & Datar & $\begin{array}{l}\text { Kompleks Litosol } \\
\text { Mediteran dan } \\
\text { Renzina }\end{array}$ & Sawah \\
\hline 3. & $\begin{array}{l}\text { Formasi Wonosari (Tmwl): } \\
\text { Batu gamping koral, batu } \\
\text { gamping lempungan- } \\
\text { Tuffan-pasiran, napal, batu } \\
\text { lempung hitam bergambut, } \\
\text { dan kalsidurit }\end{array}$ & Landai & $\begin{array}{l}\text { Kompleks Litosol } \\
\text { Mediteran dan } \\
\text { Renzina }\end{array}$ & Tegalan \\
\hline 4. & $\begin{array}{l}\text { Formasi Mandalika } \\
\text { (Tomm): lava andesit- } \\
\text { basalt, latitporfiri, riolit, } \\
\text { dan dasit. }\end{array}$ & Landai & $\begin{array}{l}\text { Kompleks } \\
\text { Litosol, } \\
\text { Mediteran dan } \\
\text { Renzina }\end{array}$ & Tegalan \\
\hline 5. & $\begin{array}{l}\text { Formasi Wonosari (Tmwl): } \\
\text { Batu gamping koral, batu } \\
\text { gamping lempungan- } \\
\text { Tuffan-pasiran, napal, batu } \\
\text { lempung hitam bergambut, } \\
\text { dan kalsidurit }\end{array}$ & Landai & $\begin{array}{l}\text { Kompleks } \\
\text { Litosol, } \\
\text { Mediteran dan } \\
\text { Renzina }\end{array}$ & Tegalan \\
\hline 6. & $\begin{array}{l}\text { Formasi Mandalika } \\
\text { (Tomm): lava andesit- } \\
\text { basalt, latitporfiri, riolit, } \\
\text { dan dasit. }\end{array}$ & $\begin{array}{l}\text { Sangat } \\
\text { curam }\end{array}$ & $\begin{array}{l}\text { Kompleks } \\
\text { Mediteran Coklat } \\
\text { Kemerahan }\end{array}$ & Tegalan \\
\hline 7. & $\begin{array}{l}\text { Formasi Mandalika } \\
\text { (Tomm): lava andesit- } \\
\text { basalt, latitporfiri, riolit, } \\
\text { dan dasit. }\end{array}$ & Curam & $\begin{array}{l}\text { Kompleks } \\
\text { Litosol, } \\
\text { Mediteran dan } \\
\text { Renzina }\end{array}$ & $\begin{array}{l}\text { Semak } \\
\text { belukar }\end{array}$ \\
\hline 8. & $\begin{array}{l}\text { Formasi Mandalika } \\
\text { (Tomm): lava andesit- } \\
\text { basalt, latitporfiri, riolit, } \\
\text { dan dasit. }\end{array}$ & Curam & $\begin{array}{l}\text { Kompleks } \\
\text { Litosol, } \\
\text { Mediteran dan } \\
\text { Renzina }\end{array}$ & Tegalan \\
\hline
\end{tabular}

\subsection{Lokasi Pengambilan Sampel 3: Dusun Mentaraman (656666, 9091521 UTM 49S)}

Pengambilan sampel ketiga berada di Dusun Mentaraman. Pada titik ini kondisi topografinya landai dengan tutupan vegetasi yang lebat. Kondisi ini diasumsikan dengan keberadaan potensi air tanah yang besar. Selain itu, dengan posisi topografi wilayah ini mempermudah penduduk untuk memanfaatkan air tanah. Berdasarkan perhitungan nilai resistivitas, potensi keterdapatan air tanah pada lokasi ini diperkirakan berada di kedalaman 
Jurnal Pendidikan Geografi:

Kajian, Teori, dan Praktik dalam Bidang Pendidikan dan Ilmu Geografi

$$
\text { 27(1), 2022, 102-116 }
$$

4-8 m (Gambar 6). Lapisan ini diinterpretasikan sebagai batu pasir yang berada pada kondisi jenuh air (akuifer).

Hasil pemodelan untuk perlapisan hidrostratigrafi dapat diklasifikasikan menjadi: 1) Akuiklud, 2) Akuitar, 3) Akuifug untuk lintasan 2. Keberadaan air tanah dimungkinkan terdapat pada lapisan akuitar dengan kapasitas air terbatas sebab lapisan ini diinterpretasikan sebagai breksi. Kondisi hidrostratigrafi lokasi pengambilan sampel digambarkan pada Gambar 9.

\subsection{Lokasi Pengambilan Sampel 4: Dusun Sumbertimo Lintasan 1 (654769, 9090632 UTM 49S)}

Sampel keempat diambil di Dusun Sumbertimo. Titik lokasi berada pada kondisi lereng yang landai dengan jenis penggunaan lahan berupa tegalan. Berdasarkan perhitungan nilai resistivitas, potensi keterdapatan air tanah pada lokasi ini diperkirakan berada di kedalaman 10-175 m (Gambar 10). Lapisan ini diinterpretasikan sebagai batu pasir yang berada pada kondisi jenuh air (akuifer). Jenis material pada lapisan ini mampu menyimpan dan meloloskan air dalam jumlah besar.

\subsection{Lokasi Pengambilan Sampel 5: Dusun Sumbertimo Lintasan 2 (654936, 9090751 UTM 49S)}

Lokasi pengambilan sampel kelima masih berada di Dusun Sumbertimo namun berbeda secara kondisi geologis regionalnya. Titik sebelumnya berada pada Formasi Mandalika dan titik sampel kelima ini berada pada Formasi Wonosari. Pada titik ini kondisi kemiringan lereng adalah landai. Berdasarkan perhitungan nilai resistivitas, potensi keterdapatan air tanah pada lokasi ini diperkirakan berada di kedalaman 20-40 m (Gambar 11). Lapisan ini diinterpretasikan sebagai batu pasir yang berada pada kondisi jenuh air (akuifer). Dengan kondisi tersebut maka diasumsikan penduduk akan mudah memanfaatkan air.

\subsection{Lokasi Pengambilan Sampel 6: Dusun Tumpakmiri Lintasan 1 (655436, 9089640 UTM 49S)}

Berdasarkan perhitungan nilai resistivitas, potensi keterdapatan air tanah pada lokasi ini diperkirakan berada di kedalaman 7-28 m (Gambar 12). Lapisan ini diinterpretasikan sebagai batu pasir yang berada pada kondisi jenuh air (akuifer). Lokasi pengambilan sampel keenam dapat dijelaskan bahwa potensi lapisan akuifer berada pada bagian perpotongan lereng. Lokasi sampel ini tidak jauh dari permukiman pada lereng atas sehingga akan mempermudah distribusi pemanfaatan air tanah.

\subsection{Lokasi Pengambilan Sampel 7: Dusun Tumpakmiri Lintasan 2 (65494, 9089703 UTM 49S)}

Berdasarkan perhitungan nilai resistivitas, potensi keterdapatan air tanah pada lokasi ini diperkirakan berada di kedalaman 5-20 m (Gambar 13). Akan tetapi, potensi air tanah pada lokasi ini berada di tingkat yang terbatas sebab lapisan ini diinterpretasikan sebagai batu lempung pasiran yang juga berfungsi sebagai akuitar. Pada lokasi pengambilan sampel ketujuh ini berpotensi adanya lapisan akuifer pada bagian perpotongan lereng. Keberadaan lintasan 


\section{Jurnal Pendidikan Geografi:}

Kajian, Teori, dan Praktik dalam Bidang Pendidikan dan Ilmu Geografi

$$
\text { 27(1), 2022, 102-116 }
$$

kedua di Dusun Tumpakmiri berada tidak jauh pada lokasi permukiman pada lereng atas sehingga akan mempermudah distribusi pemanfaatan air tanah.

\subsection{Lokasi Pengambilan Sampel 8: Dusun Tumpakmiri Lintasan 3 (654752, 9089643 UTM 49S)}

Berdasarkan perhitungan nilai resistivitas, potensi keterdapatan air tanah pada lokasi ini diperkirakan berada di kedalaman 2-32 m (Gambar 14). Lapisan ini diinterpretasikan sebagai batu pasir yang berada pada kondisi saturated (akuifer). Lapisan pada lokasi ini dapat dikategorikan pada akuifer dangkal.

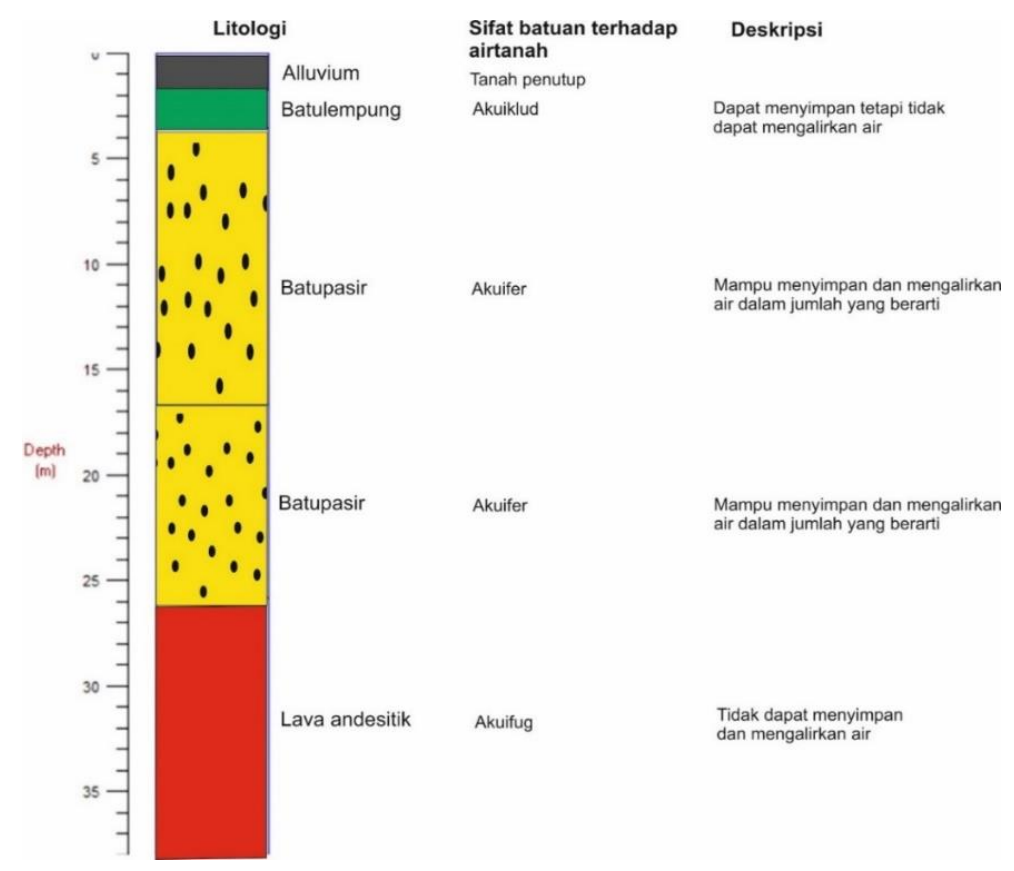

Gambar 7. Hidrostratigrafi Kedungwaru 1

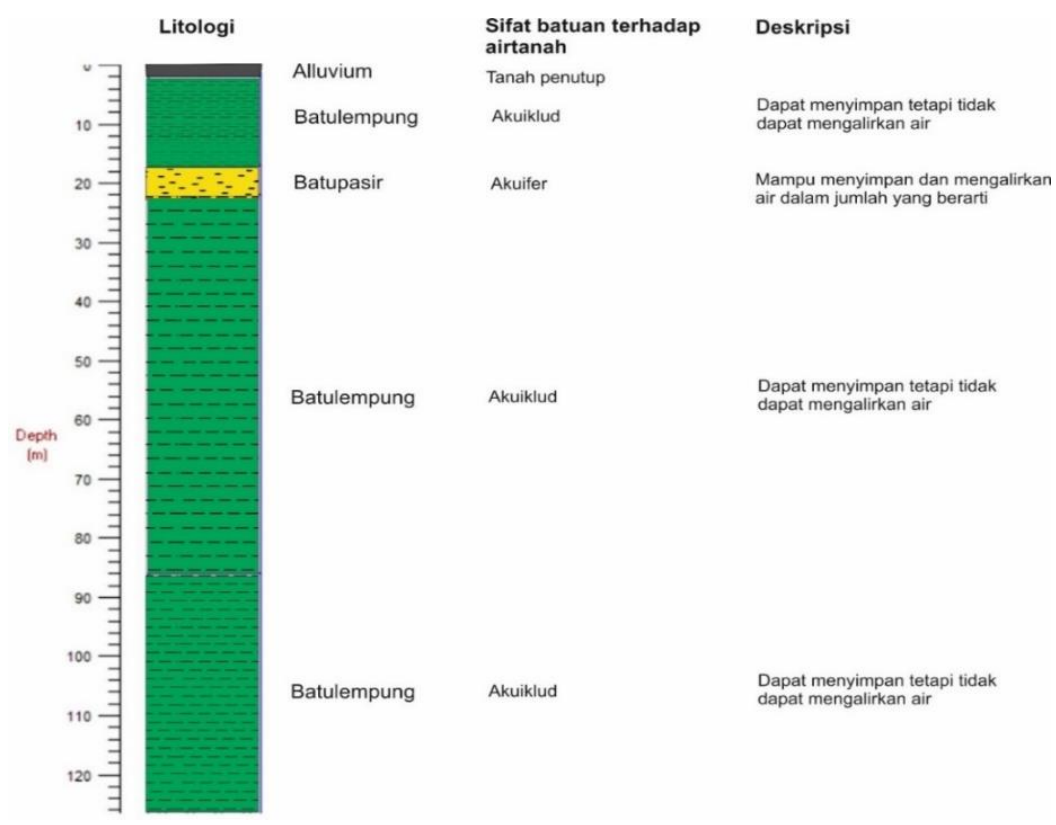

Gambar 8 . Hidrostratigrafi Kedungwaru 2 
Jurnal Pendidikan Geografi:

Kajian, Teori, dan Praktik dalam Bidang Pendidikan dan Ilmu Geografi

$27(1), 2022,102-116$

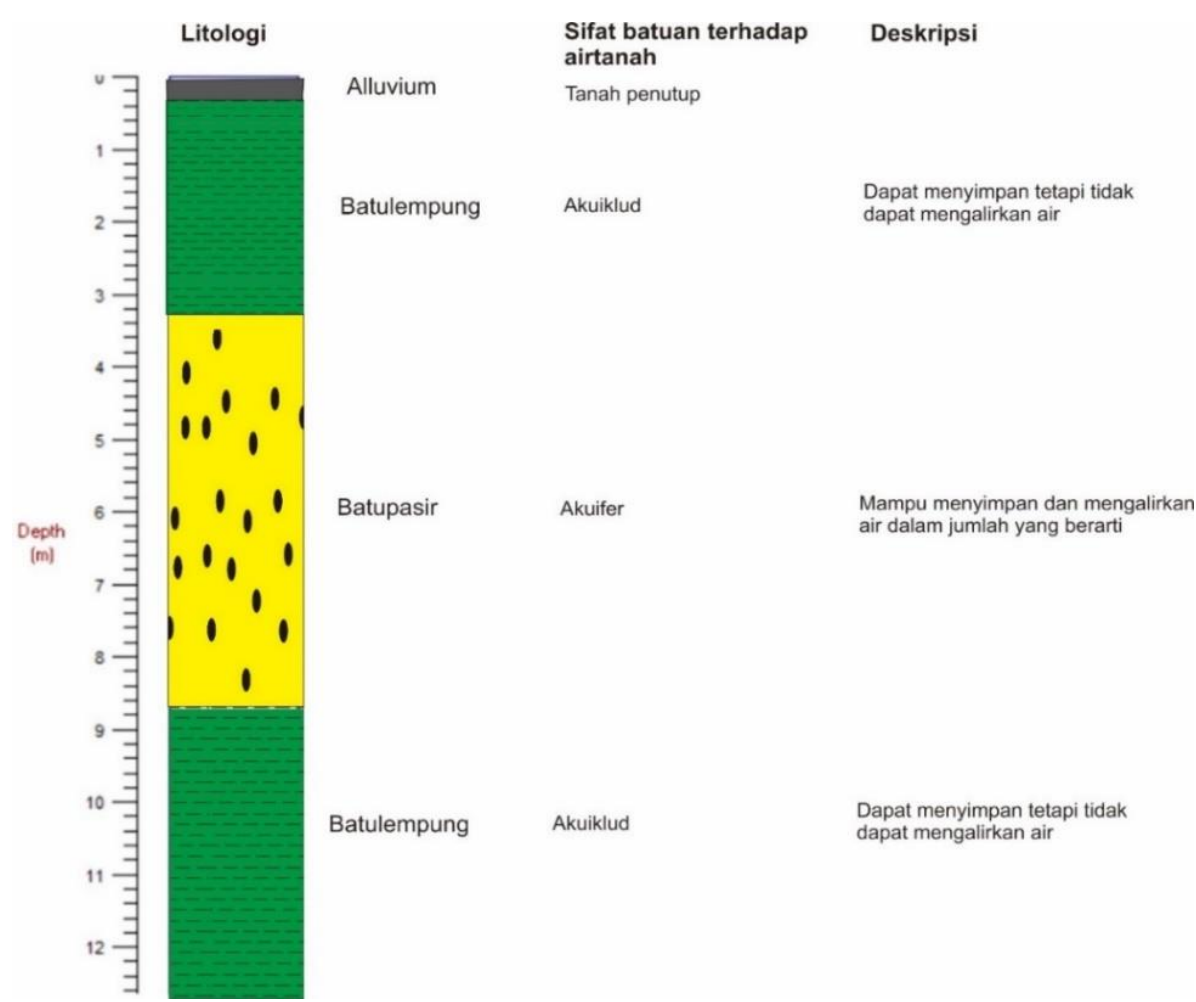

Gambar 9. Hidrostratigrafi Mentaraman

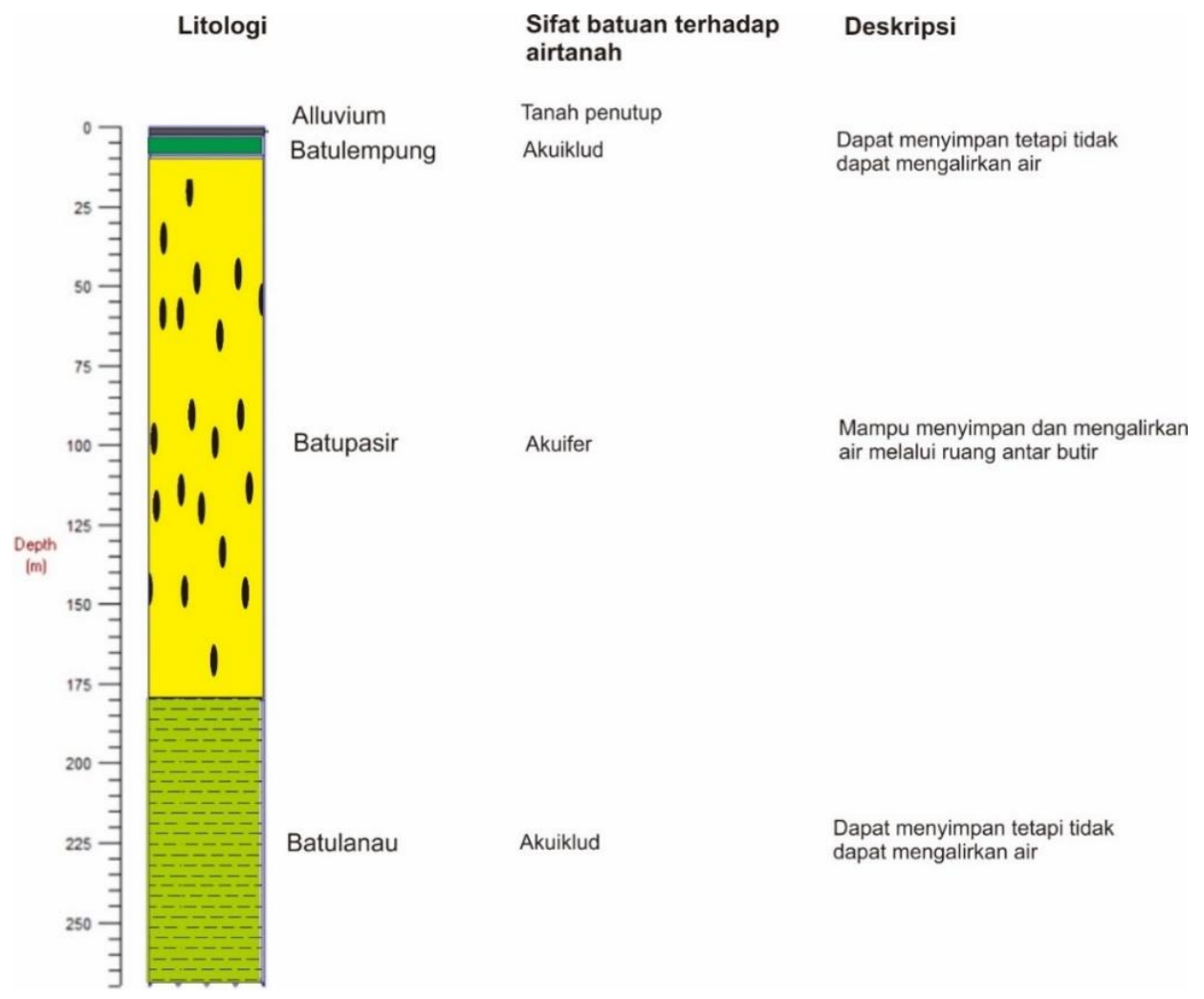

Gambar 10. Hidrostratigrafi Dusun Sumbertimo Lintasan 1 
Jurnal Pendidikan Geografi:

Kajian, Teori, dan Praktik dalam Bidang Pendidikan dan Ilmu Geografi

$27(1), 2022,102-116$

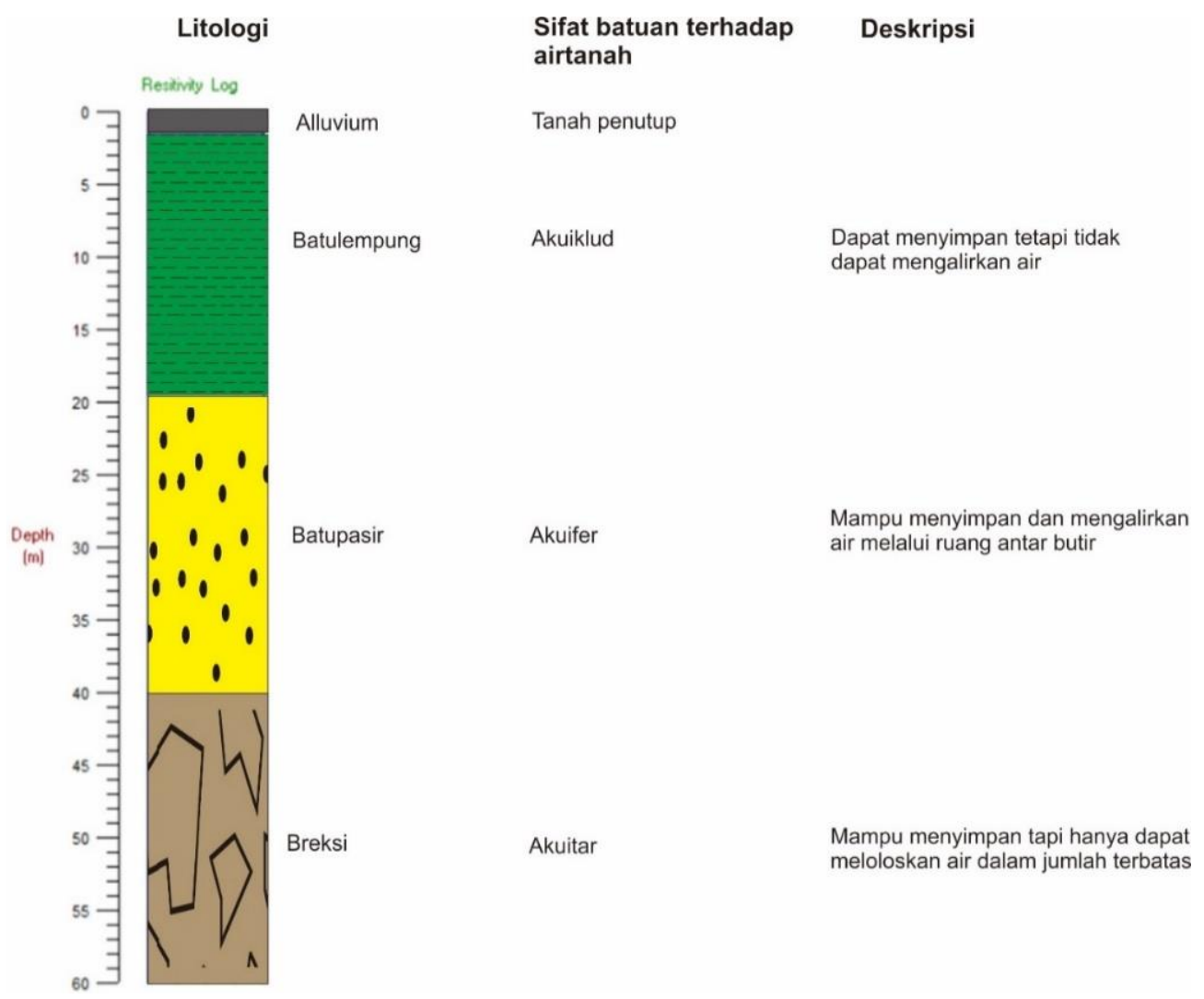

Gambar 11. Hidrostratigrafi Dusun Sumbertimo Lintasan 2

Litologi Sifat batuan terhadap Deskripsi

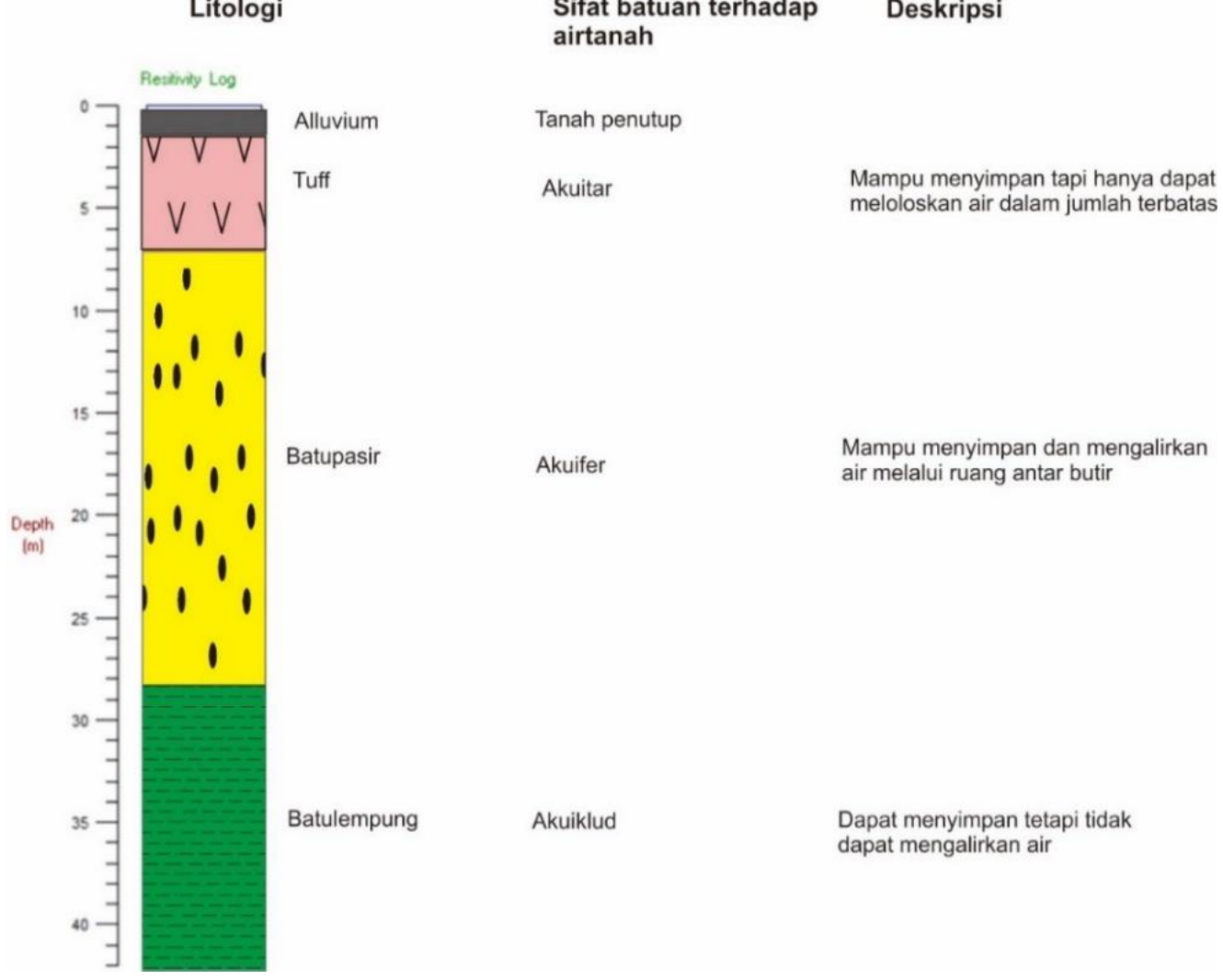

Gambar 12. Hidrostratigrafi Dusun Tumpakmiri Lintasan 1 
Jurnal Pendidikan Geografi:

Kajian, Teori, dan Praktik dalam Bidang Pendidikan dan Ilmu Geografi

$27(1), 2022,102-116$

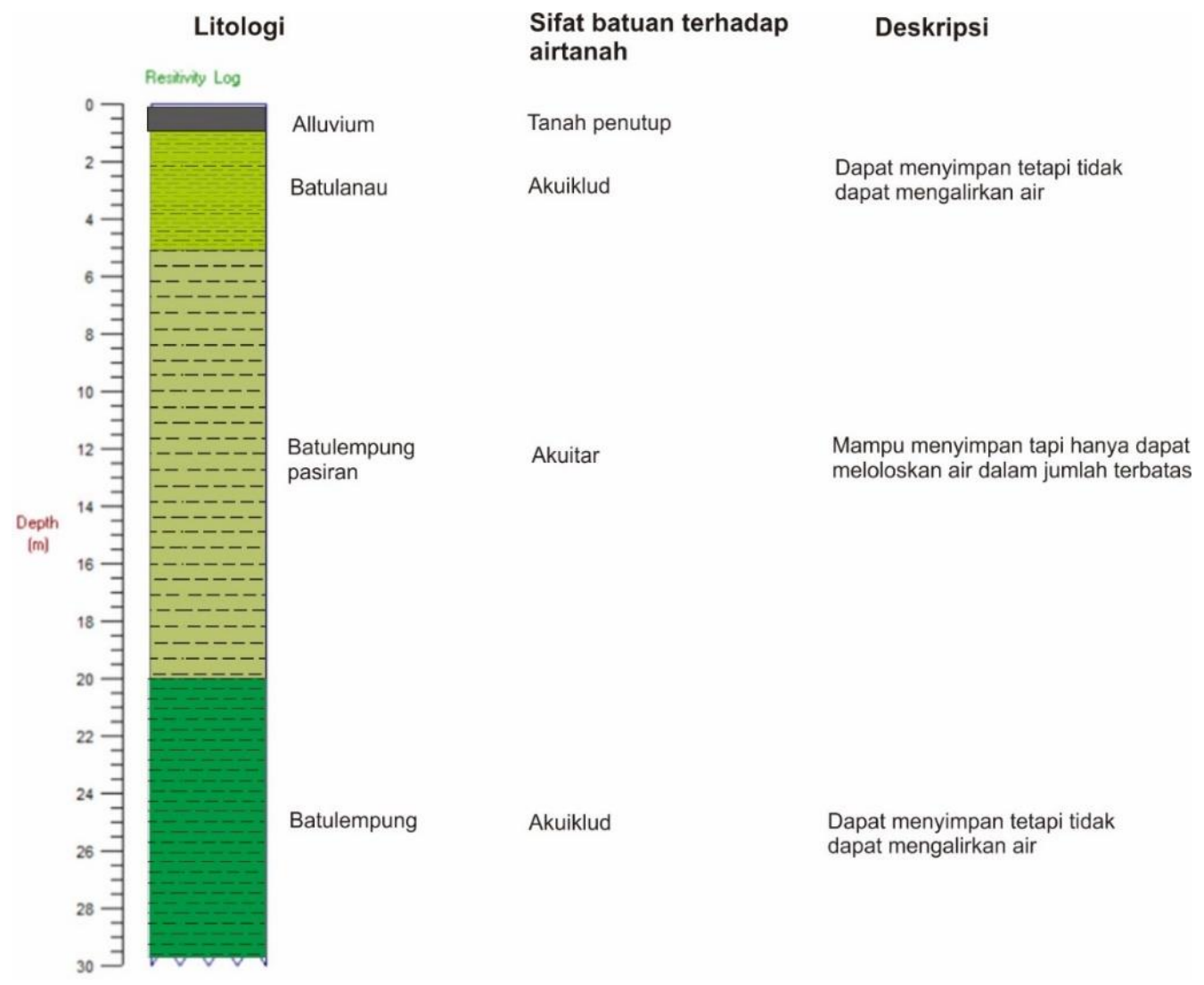

Gambar 13. Hidrostratigrafi Dusun Tumpakmiri Lintasan 2

Litologi

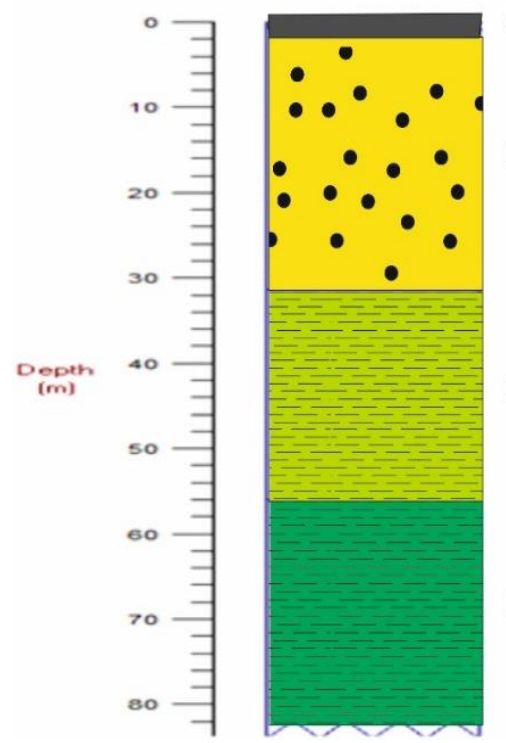

Sifat batuan terhadap airtanah

Alluvium

Batupasir

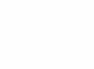

Batulanau

Batulempung

Tanah penutup

Akuifer

Akuiklud

Akuiklud
Mampu menyimpan dan mengalirkan air melalui ruang antar butir

Dapat menyimpan tetapi tidak dapat mengalirkan air

Dapat menyimpan tetapi tidak
Deskripsi

dapat mengalirkan ai

Gambar 14. Hidrostratigrafi Dusun Tumpakmiri Lintasan 3 


\section{Simpulan}

Desa Arjosari merupakan salah satu wilayah di Kecamatan Kalipare, Kabupaten Malang dengan kondisi ketersediaan air bersih yang terbatas. Kondisi ini berakibat pada ketidakmampuan pemenuhan kebutuhan air bersih bagi penduduk khususnya pada saat musim kemarau. Saat ini kebutuhan air bersih penduduk di Desa Arjosari bertumpu pada beberapa sumber air meliputi: sumur dalam (sumur bor), sumur dangkal (gali), dan mata air. Berdasarkan hasil penelitian diperoleh delapan titik potensi air tanah yang dapat dimanfaatkan penduduk Desa Arjosari untuk memenuhi kebutuhan air. Pengetahuan ini sangat bermanfaat dalam upaya pemenuhan kebutuhan air bagi penduduk dan manajemen tata kelola air di masyarakat. Di sisi lain, penelitian ini bermanfaat untuk menambah khasanah pengetahuan dan terapan ilmu geohidrologi khususnya dalam hal identifikasi dan deteksi keberadaan potensi air tanah.

\section{Daftar Rujukan}

Akintorinwa, O. J. and A. 0. (2012). Comparison of Schlumberger and modified Schlumberger arrays ves interpretation results. Research Journal in Engineering and Applied Sciences.

Astutik, P., Wahyono, C., \& Sadok, S. (2016). Identifikasi intrusi air laut menggunakan metode geolistrik di Desa Kampung Baru, Tanah Bumbu. Jurnal Fisika FLUX: Jurnal Ilmiah Fisika FMIPA Universitas Lambung Mangkurat.

Bharti, A. K., Pal, S. K., Singh, K. K. K., Singh, P. K., Prakash, A., \& Tiwary, R. K. (2019). Groundwater prospecting by the inversion of cumulative data of Wenner-Schlumberger and dipole-dipole arrays: A case study at Turamdih, Jharkhand, India. Journal of Earth System Science, 128(4), 1-10.

BPS Kabupaten Malang. (2021). Kecamatan Kalipare dalam angka 2021.

Darwis, D. (2018). Pengelolaan air tanah di Indonesia. In A. Kodir (Ed.), Pena Indis (Pertama). Yogyakarta: Pena Indis.

Fajana, A. O., Sanuade, O. A., Olawunmi, O. T., \& Oyebamiji, A. R. (2019). Comparison of conventional Schlumberger and modified Schlumberger arrays in estimating aquifer parameters in a typical basement complex, Southwestern Nigeria. FUOYE Journal of Engineering and Technology. https://doi.org/10.46792/fuoyejet.v4i1.306

Faris, A. N., Suaidi, D. A., Sutrisno, S., Hasan, M. F. R., \& Broto, A. B. (2019). Identification of aquifers distribution using geoelectric-resistivity method with Schlumberger configuration in Gedangan Village, Malang Regency. Natural B, Journal of Health and Environmental Sciences, 5(1), 28-34.

Finke, P. A., Brus, D. J., Bierkens, M. F. P., Hoogland, T., Knotters, M., \& De Vries, F. (2004). Mapping groundwater dynamics using multiple sources of exhaustive high resolution data. Geoderma, 123(1-2), 23-39.

Fitrianto, T. N., Supriyadi, S., Taufiq, U. A., Mukromin, T. M., \& Wardana, A. P. (2018). Identifikasi potensi air tanah menggunakan metode geolistrik resistivitas konfigurasi Schlumberger di Kelurahan Bapangsari Kecamatan Bagelen Kabupaten Purworejo. Jurnal Fisika FLUX Jurnal Ilmiah Fisika FMIPA Universitas Lambung Mangkurat. https://doi.org/10.20527/flux.v15i2.4954

Ismawan, M. F. (2016). Kajian intrusi air laut dan dampaknya terhadap masyarakat di pesisir Kota Tegal. GeoImage, 5(1).

Mishra, N., Khare, D., Gupta, K. K., \& Shukla, R. (2014). Impact of land use change on groundwater-a review. Advances in Water Resource and Protection, 2(28), 28-41.

Nurwidyanto, M. I., Yustiana, M., \& Widada, S. (2006). Pengaruh ukuran butir terhadap porositas dan permeabilitas pada batu pasir. Berkala Fisika, 9(4), 191-195.

Oladunjoye, M., \& Jekayinfa, S. (2015). Efficacy of hummel (modified Schlumberger) arrays of vertical electrical sounding in groundwater exploration: Case study of parts of ibadan metropolis, Southwestern Nigeria. International Journal of Geophysics. https://doi.org/10.1155/2015/612303

Rubiantoro, P. (2016). Pemanfaatan metode geolistrik resistivitas konfigurasi Schlumberger dalam pendugaan lapisan akuifer untuk potensi air tanah di Desa Cemara Kecamatan Suboh Kabupaten Situbondo. Integrated Lab Journal, 4(1). 
Jurnal Pendidikan Geografi:

\section{Kajian, Teori, dan Praktik dalam Bidang Pendidikan dan Ilmu Geografi}

$27(1), 2022,102-116$

Shah, T. (2008). India's master plan for groundwater recharge: An assessment and some suggestions for revision. Economic and Political Weekly, 41-49.

Shantharam, Y., \& Elangovan, K. (2018). Groundwater potential zones delineation using geo-electrical resistivity method and GIS for Coimbatore, India. Indian Journal of Geo-Marine Sciences.

Sharma, K. D. (2009). Groundwater management for food security. Current Science, 96(11), 1444-1447.

Supriyadi, S., Khumaedi, K., \& Putro, A. S. P. (2017). Geophysical and hydrochemical approach for seawater intrusion in north Semarang, Central Java, Indonesia. International Journal of GEOMATE. https://doi.org/10.21660/2017.31.50405

Uligawati, G. W., \& Fatimah, F. (2020). Identifikasi akuifer dengan metode geolistrik konfigurasi Schlumberger di Daerah Ponjong, Gunung Kidul. Geoda, 1(1), 1-7.

Winarni, E. A. T., Darsono, D., \& Legowo, B. (2014). Aplikasi metode geolistrik resistivitas konfigurasi Schlumberger untuk identifikasi akuifer di Kecamatan Plupuh, Kabupaten Sragen. Jurnal Fisika Flux: Jurnal Ilmiah Fisika FMIPA Universitas Lambung Mangkurat, 11(2), 118-126. 